\title{
Article
}

\author{
Doi 10.5943/sif/6/1/12
}

\section{Endophytic fungi: a source of potential anticancer compounds}

\author{
Palwe SD ${ }^{1, *}$, Borde $\mathrm{MY}^{2}$ and Sonawane $\mathrm{HB}^{3}$ \\ ${ }^{1}$ Department of Botany, MGV's ASC College Surgana, Dist. - Nashik-422 211, India \\ ${ }^{2}$ Mycology Laboratory Department of Botany, Savitribai Phule Pune University, Ganeshkhind, Pune - 411 007, India \\ ${ }^{3} P G$ Research Centre in Botany, PDEA's Prof. Ramkrishna More ACS College Akurdi, Pune - 411 044, India
}

Palwe SD, Borde MY, Sonawane HB 2021 - Endophytic fungi: a source of potential anticancer compounds. Studies in Fungi 6(1), 188-203, Doi 10.5943/sif/6/1/12

\begin{abstract}
Bioactive metabolites produced by different endophytic fungi have wide range of applications in pharmaceutical and herbal medicine research. In contrast to plants, they are barely investigated to their boundless possibilities as storehouses of novel bioactive metabolites. They produce diverse metabolites by different biosynthetic pathways with the host plant. Enthusiasm for endophytes as a characteristic asset for new drugs was roused by the disclosure of paclitaxel-producing endophytic fungi. Anticancer activity is by and large connected with the cytotoxicity of the compounds present in the endophytic fungi. Phylogenetic classification of endophytic fungi is of great interest to mycologists as they can produce novel bioactive compounds with antitumor activity. This article audits anticancer compounds derived from endophytic fungi disengaged from the separate host plant. The endophytic fungi have been grouped by their host plants and anticancer compound synthesized.
\end{abstract}

Key words - antitumor activity - bioactive metabolites - classification - host plant - isolation

\section{Introduction}

Mycology is an imperative area that has exhibited various applications in medicine, agriculture, and environment. Natural product development has regained interest due to low production costs, structural diversity, and several uses of therapeutic compounds to treat various diseases. Medicinal plants have been used for generations to treat many diseases (Alvin et al. 2014). In current cancer therapy, there is high predominance of resistance and side effects of anticancer compounds (El-hawary et al. 2020). Endophytic fungi are interesting source of bioactive metabolites. They are able to produce similar metabolites to those produced by their host plant (Daenen et al. 2014, Ratnaweera et al. 2015, Roy 2017, Omeje et al. 2017, Deshmukh et al. 2018). Endophytes are the life forms inhabiting inside plant tissues without damage their hosts and may play critical roles in protection and development advancement (Alvin et al. 2014). Endophytes are an exceptionally common and diverse group of microorganisms that live inside-tissues of the host without causing noticeable disease to the plant (Borges et al. 2009). Both fungi and bacteria are the most common microorganisms existing as endophytes, but endophytic fungi produces huge amount of secondary metabolites with medicinal properties (Staniek et al. 2008).

There are two broad groups of endophytic fungi, C-endophytes (clavicipitaceous) and NCendophytes (non clavicipitaceous). Clavicipitaceous endophytes found in some genera of grasses and they are transmitted by vertical transfer of fungi on to offspring via infections to seed (Dias et al. 2012). Non-clavicipitaceous endophytic fungi are found in asymptomatic tissues of cryptogamic plants, conifers and most of the angiosperms (Rodriguez et al. 2009, Mishra et al. 2014). Capacity 
to produce useful anticancer compound by these fungi appears to depend on the host species, host genotype and environmental conditions (Saikkonen et al. 1999, Nazir \& Rahman 2018).

The effect of climate on endophytic fungi population and studied the temporal changes in relative frequency of total endophytic fungi. They also stated that there is a great diversity of a population of endophytic fungi among plant kingdom. Even in same population of plant, it shows diversity according to geography and environment (Chareprasert et al. 2006, Yan et al. 2019).

The host plant protects endophytes and provides nutrients and in turn, these endophytes help plant in their growth and also produce secondary metabolites which help the plant defense against plant pathogens (Tan \& Zou 2001).

The metabolic communications of endophytes with its host may support the combination of organically dynamic auxiliary metabolites. The metabolites paeonol from Chaetomium spp., citrinin from Penicillium citrinum, taxol from Taxomyces spp., piperine from Periconia spp. and many more shows bioactivity (Varma et al. 2011, Lakshmi \& Selvi 2013, Alvin et al. 2014, Li et al. 2015). The host plant is being benefited by their endophytes by increasing their immunity power and by enhancing secondary metabolites production which is useful in various industries (Strobel et al. 2004, Hyde et al. 2019).

In this review, we provide a general overview on isolation, identification and cultivation strategies of endophytic fungi having anticancer potential. Herein, we discuss the significance of bioactivity and anticancer agents from endophytic fungi.

\section{Significance of endophytic fungi for bioactivity}

It has been reported that secondary metabolites of plant origin have widely used as traditional source of medically potential drugs (Strobel et al. 2004). There is a decline of interest in recent implementation in drug development. In addition, the challenges of drug resistance require very drastic drug development approaches (Cragg \& Newman 2005).

In early phases of civilization, the man tried plants for their food and ethnomedicinal purpose. The current research approaches have responsible for the discovery of plant compounds having bioactivity with respect to their use in medications and treatments (Mishra \& Tiwari 2011). The majority of the natural bioactive compounds anticipate disclosure with the test being the manner by which to get to this characteristic compound decent variety (Rey-Ladino et al. 2011).

The main source of bioactive natural plant products has always depended heavily upon whole plant tissues such as roots, leaves, stem, fruit, and rhizome (Dias et al. 2012). Unfortunately, use of the whole plant has serious challenges and this leads to a destruction of the whole plant over time as these plant parts are repeatedly collected without replenishment, and most of the times these valuable species become endangered and are even lost in near future. This leads to degradation of the environment such as land deterioration, ecological corruption and the typically limited yield of bioactive lead compounds (Strobel \& Daisy 2003). The utilization of entire plant tissues for separation of the bioactive characteristic compound has nearly seen extraordinary wastage of research assets because of dereplication. Dereplication is the procedure of fastly identifying the known biomolecules, which results in a decrease of enthusiasm for research and is time and assets devouring (Omeje et al. 2017).

It appeared that, from last few decades, drug discovery for novel biomolecules has refocused and centered on the microorganisms that inhabit these specific host plants (Hodkinson et al. 2019). Of these living beings, endophytes were immediately perceived as veritable wellsprings of novel bioactive metabolites. Endophytes developing in different aberrant conditions have remarkable source of novel compounds possessing the natural abilities. In all these, the endophytic communities have been appeared to be astoundingly helpful in the medication revelation process. An escalated writing review uncovered that endophytic populaces of the plants in rainforests of the greater part of the mainlands have not been altogether investigated. There is a need to awaken and boost research interest in the use of these endophytic fungi for the discovery of potent bioactive molecules against the ever-increasing global disease burden (Omeje et al. 2017, Saha et al. 2019).

Also, given the quickly expanding worldwide populace and the going with interest for 
medications, it is fundamentally vital to recognize and create inexhaustible wellsprings of pharmaceuticals and their forerunners (Strobel \& Daisy 2003, Mishra \& Tiwari 2011).

\section{Search for active metabolites and endophytic fungi}

In a period of nearly two decades, the available data reveals that more than $40 \%$ of novel bioactive compounds obtained, out of which half were derived from microorganisms (Porras-Alfaro \& Bayman 2011). Moreover, over $60 \%$ of the anticancer and $70 \%$ of the antimicrobial medications right now in clinical use are herbal products or its characteristic product subsidiaries (Omeje et al. 2017). The extraordinary microbial decent diversity with energizing metabolic buildings in plant tissues has been set up over the most recent two decades and is proceeding (Porras-Alfaro \& Bayman 2011). About 10 years back, the scan for novel auxiliary metabolites ought to be refocused and examine endeavours thusly fixated on the organisms that occupy one of the kind biotopes (Mishra \& Tiwari 2011). Of these living beings, endophytes were perceived as assorted wellsprings of bioactive metabolites on the grounds that the majority of them involving actually a huge number of one of a kind higher plants developing in a differing strange condition. Renewability, ready availability and environmental friendliness are very interesting features of the endophytic fungi which are probable sources of biologically active natural products. It is realized that these endophytic fungi are profound pull in a plant for a critical piece of their life cycle and, they cannot create ailments in the host. This quality makes this class of microorganisms an extraordinary asset base for the disclosure and advancement of powerful anticancer particles without collecting the entire plant and its tissues (Bacon \& White 2000, Souvik et al. 2012, Omeje et al. 2017).

It was recently believed that metabolic compounds are exchanged between the host plant and the endophyte by the hypothesis of flat exchange (horizontal transfer) from the host plant to its microbial symbiont (Stierle at al. 1993, Strobel 2006, Puri et al. 2006, Kusari et al. 2009b, Omeje et al. 2017). This conviction has been invalidated after the effective sequencing of the taxadiene synthase quality from the taxol creating endophyte which set up that the metabolic pathways of both the hosts and the endophytes are autonomous of one another. The ramifications of this are there are substantial open doors accessible for the control of the endophyte biosynthetic pathways to yield wide assortments of metabolites and a stage for medication disclosure process (Staniek et al. 2008, Omeje et al. 2017). As indicated by fossilized tissues of plant and related microorganisms has uncovered that endophyte-plant communications may have advanced from when higher plants initially showed up on the earth surface. De-Bary first proposed the term 'endophyte' that being of fungus or bacteria in the inner tissues of healthy plants, which are capable of living and colonizing without causing noticeable symptoms of diseases (De Bary 1866, El-hawary et al. 2020).

Since the discovery of endophytes, they have been isolated from a variety of organs from diverse plant families ranging from bryophytes, pteridophytes, gymnosperms, and angiosperms from various ecosystems. The fungi, bacteria, and actinomycetes have shown the most frequent occurrence (Arnold 2007, Li et al. 2008). It was known that the endophytic fungi were existed in the plant organs (Redecker et al. 2000). Endophytic fungi are the individual from an exceptionally differing polyphyletic group of microorganisms; they can develop asymptomatically in the plant tissues over the ground and subterranean, including stems, leaves as well as roots (Selim et al. 2012). Numerous endophytes can integrate an assorted cluster of metabolites and some of them utilized as remedial specialists against different human illnesses (Debbab et al. 2009, Aly et al. 2010, Khawar et al. 2011). Paclitaxel and podophyllotoxin are some examples of occasionally discovered endophytes derived plant secondary metabolites having therapeutic potential (Stierle et al. 1993, Puri et al. 2006).

Bioactive compound production by endophytic fungi without their host plant is important from a biochemical, ecological and molecular perspective. Direct use of medicinal plants has a common problem of dereplication. To avoid such problem, there is the necessity to exploit endophytic fungi for production of a variety of novel biologically active secondary metabolites (Omeje et al. 2017).

The endophytic fungi capacity is further limited by the presence of unknown biosynthetic 
pathways that remain unexpressed under in vitro conditions (Hertweck 2009). Be that as it may, distinctive strategies worried to the development and control of endophytic fungi, for example, coculture, synthetic enlistment, epigenetic tweak, and media designing, metabolite redesigning, bioprocess innovation for scale-up, make them appropriate for the generation of known and novel bioactive compounds (El-Amrani et al. 2012).

The terrestrial ecosystems have more biodiversity in tropical and temperate rainforests (Forseth 2010). The endemic plant species have specific endophytes that may have evolved simultaneously with each other. The active species with variety of metabolites survived the most in evolutionary race due to constant chemical rearrangements in ecosystems. Tropics are the great source of novel metabolites due to high competition, limited resources and heavy selection pressure (Redell \& Gordon 2000, Omeje et al. 2017).

\section{Isolation of endophytic fungi}

Proper information is required for selection of plants for the study of endophytic fungi while searching novel bioactive compounds. Since the biochemical and metabolic pathways of both endophytic fungi and host plant are strongly correlated, it is convenient to use medicinally important plants for the bioprospecting of endophytic fungi for novel secondary metabolites having therapeutic potential.

For the isolation of endophytic fungi, there is a need to collect asymptomatic tissues from the plant such as fruit, leaves, root, secondary branches and stem in sterile plastic bags and stored at $4^{\circ} \mathrm{C}$ temperature to ensure the integrity of the plant part (Dastogeer et al. 2020). Throughout the regular process of endophytic fungi isolation, there is a need to maintain total aseptic conditions for avoiding contaminations in the culture. The accompanying techniques are then pursued:

1. Collect an external part of host plant and wash thoroughly under running tap water for approximately $10 \mathrm{~min}$ to remove adhering soil particles and debris, then dry on a sterile filter paper towel.

2. Use a sterilized scalpel or hole puncher to excise pieces of the leaves and sterilize further using $95 \%$ ethanol $(30 \mathrm{sec}$.), $2 \%$ sodium hypochlorite $(\mathrm{NaOCl})(2-3 \mathrm{~min}), 70 \%$ ethanol (2 min.).

3. Wash the sterilized samples 2-3 times in sterile distilled water and allow the plant material to dry up between the folds of sterile filter papers under aseptic conditions. In practice, the isolates can be thought to be endophytic fungi when add up to surface sterilization is affirmed, i.e. no contagious development from engraving the surface sterilized plant tissues onto supplement media or refined aliquot of water from the last flushing onto supplement media.

4. Subsequently, inoculate the samples on the suitable culture media (potato dextrose agar) supplemented with an antibiotic (100-500 mg/l) to prevent the growth of unwanted bacteria (Omeje et al. 2017). Use a flame sterilized hole puncher to excise circular leaf discs from each leaf. Dice fruit pieces with a sterile scalpel to expose fresh tissue surfaces. The plating and inoculation are usually done inside laminar air flow to maintain aseptic conditions throughout the process (Sanders 2012).

5. Incubate the plates at room temperature $\left(30-37^{\circ} \mathrm{C}\right)$. Subsequently, transfer the fungal mycelium growing out from leaf discs to fresh PDA/MEA plates by hyphal tip transfers and incubate further at room temperature for 1-2 weeks (Omeje et al. 2017).

6. Check the purity of isolated endophytic fungi and study their morphological and cultural characteristics. Maintain the endophytic fungal isolates in PDA/MEA slant for future studies.

\section{Distinguishing proof of endophytic fungal isolates}

Naturally visible and minuscule attributes assume an extremely significant job in the recognizable proof of separated endophytic fungal isolates. There are a few taxonomical order 
guides accessible, for example, found in these references (Ainsworth et al. 1973, Ellis 1976, Von Arx 1978, Barnet \& Hunter 1998). Culture-subordinate strategies have been frequently utilized in the investigation of the decent variety of endophytic fungi as opposed to coordinate perception techniques. The investigation of endophytic fungi is a technique subordinate process. Some standard procedures like surface sanitization methods, incubation periods and sporulation limit of endophytic fungi apply their immediate effect on confinement of endophytes from the host plant. In this manner, culture seclusion strategy has a few constraints, for example, (1) It rather worksome and tedious and is improper to look at extensive quantities of samples and tests; (2) The expansive number of sterile endophytes represents an extraordinary issue, since they cannot be distinguished to any ordered classification, while different strategies have been utilized to advance sporulation of isolates so as to beat the inadequacies of some endophytes unfit to sporulate in culture (Guo et al. 1998, Taylor et al. 1999, Guo et al. 2000, 2008); (3) Some fungi might be missed because of inability to develop or some develop gradually and are effortlessly outperformed by quickly developing species in counterfeit conditions. So as to defeat the potential specialized predisposition, development autonomous methodologies, e.g., molecular techniques, to analyze endophytic fungal networks of plants are required.

Molecular methodologies have been effectively utilized in the recognition and distinguishing proof of endophytic fungi in leaves, establishes and mycorrhizal growths in roots and soil (Clapp et al. 1995, Chelius \& Triplett 1999, Tedersoo et al. 2008). The obstacle in the standard culturing strategies has been overcoming by use of molecular procedures like DNA sequencing and fingerprinting techniques and so forth (Fig. 1).

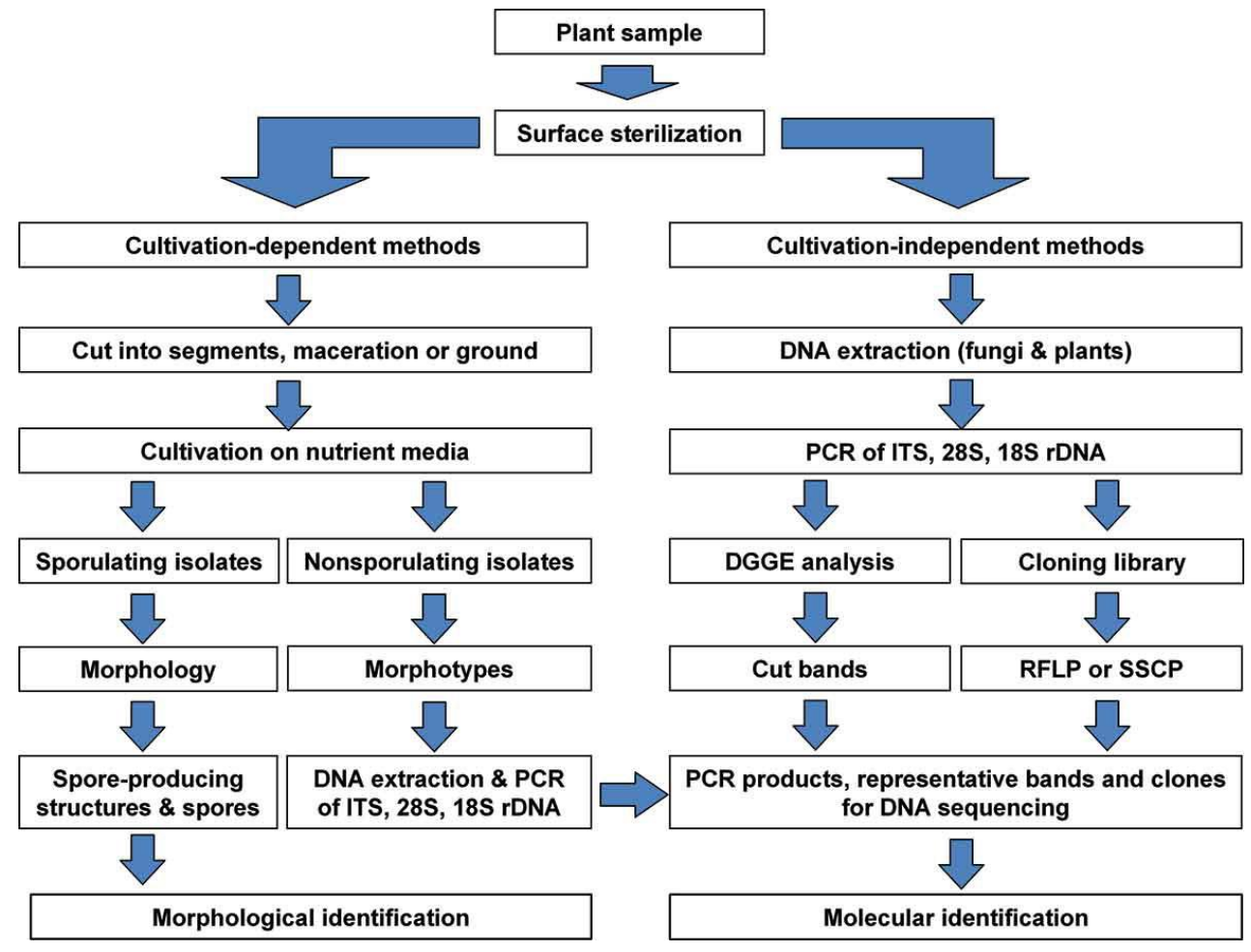

Fig. 1 - A schematic flowchart for isolation and identification of endophytic fungi (Sun \& Guo 2012).

The newfound, high throughput sequencing (pyro-sequencing) empowers metagenomic and metagenetic investigations and gives a ground-breaking elective apparatus to molecular investigations of the fungal network in common habitats. Pyrosequencing is fast, generally modest, with a free-cloning step and high product yield, which accomplishes an around 100-overlap increment in throughput over Sanger sequencing (Margulies et al. 2005). DNA barcoding methods give a short, compelling and standardized gene region to distinguish endophytic fungi at an explicit 
dimension. The DNA barcode sequence region utilized ought to be a solitary locus for all gatherings of life forms in kingdom fungi.

The significantly preferred standpoint of sequence-based characterization is that it most helpful when having plant tissues are contaminated with pathogens since specific primers are utilized for amplifying the target gene in the nearness of high DNA background of the host plant (Table 1). On another side, SSU and LSU sequences frequently don't give adequate resolution to the classification of subgeneric taxa, and genomic areas of higher diversity were scanned for. In the interim, the internal transcribed spacer (ITS) region, and to a lesser degree the IGS (inter-genic spacer) region, these two noncoding components of the nuclear rDNA have turned into the most favored sequences for concentrates on the lower ranking levels (Bachmann 1994, Schurko et al. 2003, Wattier et al. 2003).

Table 1 List of molecular techniques and their potential applications in identification of endophytic fungi

\begin{tabular}{|c|l|l|l|}
\hline Sr. No. & \multicolumn{1}{|c|}{ Technique } & \multicolumn{1}{|c|}{ Taxonomic level } & \multicolumn{1}{|c|}{ Field of application } \\
\hline 1. & $\begin{array}{l}\text { Amplified fragment length } \\
\text { polymorphism (AFLP) }\end{array}$ & Species to subspecies & Classification \\
\hline 2. & $\begin{array}{l}\text { Random amplification of } \\
\text { polymorphic DNA (RAPD) }\end{array}$ & Species to subspecies & Classification \\
\hline 3. & $\begin{array}{l}\text { Inter simple sequence repeats } \\
\text { (iSSRs) }\end{array}$ & Species to subspecies & Classification \\
\hline 4. & Isozyme analysis & Subspecies & Classification \\
\hline 5. & $\begin{array}{l}\text { Single nucleotide } \\
\text { polymorphisms (SNPs) }\end{array}$ & Species to subspecies & $\begin{array}{l}\text { Phylogeny, classification and } \\
\text { population studies }\end{array}$ \\
\hline 6. & DNA barcoding & Species & Classification \\
\hline 7. & $\begin{array}{l}\text { Cyclooxygenase 2 (COX2) } \\
\text { sequencing }\end{array}$ & Kingdom to species & Phylogeny and classification \\
\hline 8. & $\begin{array}{l}\text { Large subunit (LSU) rDNA } \\
\text { sequencing }\end{array}$ & Class to species & Phylogeny \\
\hline 9. & $\begin{array}{l}\text { Internal transcribed spacer } \\
\text { (ITS) sequencing }\end{array}$ & Family to species & Phylogeny and classification \\
\hline
\end{tabular}

\section{Large-scale endophytic fungal cultivation and extraction}

Culture media have experienced numerous changes since its origin. Culture media are of various kinds, contingent upon the wholesome development prerequisites of the microorganisms. Microorganisms require around 10 macronutrients, for example, $\mathrm{C}, \mathrm{O}, \mathrm{H}, \mathrm{N}, \mathrm{S}, \mathrm{P}, \mathrm{K}, \mathrm{Ca}, \mathrm{Mg}$ and Fe (Merchant \& Helmann 2012). The initial six components are utilized in the combination of Carbohydrates, Lipids, Proteins, and Nucleic acids and the staying four exist in the cell as cations and assume several of roles. Notwithstanding macronutrients, all microorganisms require a few micronutrients like Mn, Zn, Co, Mo, Ni, and Cu (Merchant \& Helmann 2012). These are by and the large piece of catalysts and cofactors. Microorganisms likewise require development factors, which are natural mixes.

High sugar source, the nitrogen source is required in media for the development of fungi at $\mathrm{pH} 5-6$, and a temperature from $15-37^{\circ} \mathrm{C}$ (Basu et al. 2015). There are two general sorts of fungal culture media: natural and artificial. Natural media comprise of regular biological substrates, for example, herbaceous or woody plant parts, seeds, leaves, corn supper, wheat germ, and oats (Collins et al. 2005). Natural media are normally simple to get ready yet their obscure content is a noteworthy drawback. A few models incorporate corn meal agar, potato dextrose agar, V-8 juice agar, and dung agar. Artificial media has elements of the known contents. These sorts of media can be copied with exactness each time they are made and contain characterized amount of starches, nitrogen, and nutrient sources (Basu et al. 2015).

The mass culture of the endophytic fungi is carried out using selective/enriched media and 
then inoculated into a $500 \mathrm{ml}$ or larger Erlenmeyer flasks containing suitable nutrients. Then will be incubated at room temperature for 20-30 days on a rotary shaker. The broth is then filtered and extracted with a suitable solvent like chloroform, ethyl acetate, petroleum ether (Song et al. 2019). The extract then dried over anhydrous sodium sulfate and then evaporated in a rotary evaporator under vacuum, to get ethyl acetate extracts. The dried extract will be purified using several solvent fractions and recovered for future biological activity. Further, the fractions are subjected to various chromatographical techniques such as LCMS and GCMS and purifications steps to isolate pure biomolecules. Then such bioactive molecules are tested and characterized using physicochemical and spectroscopic methods (Omeje et al. 2017).

So as to investigate the uncommon shrouded possibilities of the endophytic fungi as bona fide vault for anticancer compounds, tranquilize revelation approach should target 1) the choice and seclusion of samples from various of environments, 2) by controlling physiology of microorganisms to improve microbial natural metabolite biosynthetic pathways and 3) by hereditary change of strains for generation of manufactured microbial compounds. By exploiting these three methodologies, the yield of an extract can be enhanced, and thereby the chances of finding the novel bioactive compounds can be expanded (Omeje et al. 2017).

\section{Anticancer agents from endophytic fungi}

Cancer is a group of diseases that can harmony organ in the human body and shows uncontrolled growth of malignant cells and invasion into normal tissue. Such malignant cancer cells can travel to other body parts and produce new tumors ultimately leads to death and as such, the discovery for novel anticancer agents remains endless. This hunt has, in these advanced occasions, moved to the endophytic fungi. Novel secondary metabolites are obtained from endophytes which make them suitable therapeutic complex biochemical stage in their host plants (Tan \& Zou 2001, Owen \& Hundley 2004, Omeje et al. 2017).

At present endophytic fungi are considered the most promising sources of natural antitumor drugs owing to their wide distribution and diversity among all organisms (Omeje et al. 2017). Additionally, microorganisms that can survive in unusual environments synthesize bioactive compounds of potential therapeutic applications (Mushtaq et al. 2018). The greater interest has been developed from the past few decades to exploit the rich biochemical diversity possessed by the endophytes (Table 2). Since the revelation of taxol from a fungal endophyte, endeavors have relied upon the control and enhancement of the way of culture conditions and this methodology has created a few bioactive and novel drugs (Strobel et al. 2004).

The in vitro anticancer activity of compound terrein (4,5 dihydroxy 3 (1 propenyl) 2 cyclopenten 1 one) was evaluated against human lung cancer cell line (A 549) with the IC 50 value of $121.9 \pm 4.821 \mathrm{gml}^{-1}$ (Goutam et al. 2017). The in vitro cytotoxicity assay of chaetoglobosin $\mathrm{X}$ was effective against MFC (gastric cancer cells in mice) and H-22 (hepatic cancer cells in mice) cell lines. It displayed the strongest cytotoxicity against $\mathrm{H} 22$ cells with $\mathrm{IC}_{50}$ value $3.125 \mu \mathrm{gml}^{-1}$ and exhibited moderate cytotoxicity against MFC cells with $\mathrm{IC}_{50}$ value of $6.25 \mu \mathrm{gml}^{-1}$ (Wang et al. 2012).

Camptothecin from endophytic fungi Fusarium solani was assayed in vitro for cytotoxicity against vero cell and human prostate cell line PC3. It displayed remarkable inhibitory effects at inhibiting cell growth and inducing apoptosis on vero and PC3 cell lines in a dose dependent manner (Ran et al. 2017).

In this review, we limit our dialog to a couple of selected imperative bioactive metabolites produced by fungal endophytes from some restorative plants. In the last, some decade's different analysts have detailed work on endophytic fungi as a potential wellspring of novel bioactive hotspots for anticancer, antiparasitic, antitubercular, cancer prevention agent, insecticidal agents and immunoregulatory agents (Omeje et al. 2017).

In the present review, we are displaying a report on endophytic fungi as a potential wellspring of extraordinary anticancer compounds. Following the disclosure of the first anticancer compound, taxol from the endophytic fungus Taxomyces andreanae, a few different scientists have been 
considered as authentic vaults of anticancer compounds. The strong anticancer compound paclitaxel (Taxol) has a place with the diterpenoid class of plant-inferred bioactive agents (Stierle et al. 1993, Omeje et al. 2017).

Taxol was isolated and purified for the first time, from the bark of yew plant Taxus brevifolia from South America, before, being isolated from the endophytic fungus Taxomyces andreanae. The medication was afterword endorsed by the Food and Drug Administration (FDA), USA, for the treatment of chose malignancies (Cremasco et al. 2009, Omeje et al. 2017). The diverse sources of novel anticancer agents from endophytic fungi are enlisted in Table 2.

Table 2 List of anticancer compounds isolated from fungal endophytes

\begin{tabular}{|c|c|c|c|c|}
\hline Sr. No. & Fungal Endophyte & Host Plant & Anticancer Compound & References \\
\hline \multirow[t]{2}{*}{1.} & Acremonium spp. & Knema laurina & Brefeldin A & $\begin{array}{l}\text { Chinworrungsee et al. } \\
\text { (2008) }\end{array}$ \\
\hline & & Taxus baccata & Leucinostatin & $\begin{array}{l}\text { Strobel \& Hess } \\
\text { (1997) }\end{array}$ \\
\hline \multirow[t]{6}{*}{2.} & Alternaria spp. & Polygonum & Alternariolistisp] & Aly et al. (2008) \\
\hline & & senegalense & Alternariol 5-O-sulfate & \\
\hline & & & Alternariol 5-O-methyl ether & \\
\hline & & & Altenusin & \\
\hline & & & Desmethylaltenusin & \\
\hline & & $\begin{array}{l}\text { Clerodendrum } \\
\text { phlomidis }\end{array}$ & Squalene & $\begin{array}{l}\text { Kumaradevan et al. } \\
\text { (2015) }\end{array}$ \\
\hline 3. & Arthirnium arundinis & $\begin{array}{l}\text { Polysiphonia } \\
\text { violacea }\end{array}$ & Epiepoxydon & Klemke et al. (2004) \\
\hline 4. & Aspergillus clavatus & Taxus mairei & Brefeldin & Wang et al. (2002) \\
\hline 5. & $\begin{array}{l}\text { Aspergillus } \\
\text { fumigatus }\end{array}$ & $\begin{array}{l}\text { Cynodon } \\
\text { dactylon }\end{array}$ & 9-Deacetoxyfumigaclavine & Ge et al. (2009) \\
\hline \multirow[t]{2}{*}{6.} & $\begin{array}{l}\text { Aspergillus } \\
\text { brasiliensis }\end{array}$ & $\begin{array}{l}\text { Cynodon } \\
\text { dactylon }\end{array}$ & Rubrofusarin & Song et al. (2004) \\
\hline & & $\begin{array}{l}\text { Tabebuia } \\
\text { argentea }\end{array}$ & Lapachol & $\begin{array}{l}\text { Channabasava \& } \\
\text { Govindappa (2014) }\end{array}$ \\
\hline \multirow[t]{2}{*}{7.} & Aspergillus & Sequoia & Sequoiatones & Stierle et al. (1999) \\
\hline & parasiticus & sempervirens & Sequoiamonascin & Stierle et al. (2003) \\
\hline 8. & Aspergillus terreus & $\begin{array}{l}\text { Achyranthus } \\
\text { aspera }\end{array}$ & Terrein & Goutam et al. (2017) \\
\hline 9. & $\begin{array}{l}\text { Bartalinia } \\
\text { robillardoides }\end{array}$ & $\begin{array}{l}\text { Aegle } \\
\text { marmelos }\end{array}$ & Paclitaxel & $\begin{array}{l}\text { Gangadevi \& } \\
\text { Muthumary (2009) }\end{array}$ \\
\hline 10. & Cercospora spp. & $\begin{array}{l}\text { Fallopia } \\
\text { japonica }\end{array}$ & Cercosporene F & Feng et al. (2014) \\
\hline \multirow[t]{5}{*}{11.} & $\begin{array}{l}\text { Chaetomium } \\
\text { globosum }\end{array}$ & $\begin{array}{l}\text { Polysiphonia } \\
\text { urceolata }\end{array}$ & Chaetopyranin & Wang et al. (2006) \\
\hline & & $\begin{array}{l}\text { Imperata } \\
\text { cylindrica }\end{array}$ & Chaetoglobosin & Ding et al. (2006) \\
\hline & & Ulva pertusa & Cytoglobosin & Cui et al. (2010) \\
\hline & & $\begin{array}{l}\text { Ephedra } \\
\text { fasciculata }\end{array}$ & Globosumone & Bashyal et al. (2005) \\
\hline & & $\begin{array}{l}\text { Curcuma } \\
\text { wenyujin }\end{array}$ & Chaetoglobosin X & Wang et al. (2012) \\
\hline 12. & Floropilus chiversii & $\begin{array}{l}\text { Ephedra } \\
\text { fasciculata }\end{array}$ & Radicicol & $\begin{array}{l}\text { Turbyville et al. } \\
\text { (2006) }\end{array}$ \\
\hline 13. & $\begin{array}{l}\text { Entrophospora } \\
\text { infrequens }\end{array}$ & $\begin{array}{l}\text { Nothapodytes } \\
\text { foetida }\end{array}$ & Camptothecin & Puri et al. (2005) \\
\hline 14. & Eupenicillium spp. & $\begin{array}{l}\text { Xanthium } \\
\text { sibiricum }\end{array}$ & $\begin{array}{l}\text { Eupenicillinol C, } \\
\text { Eupenicillinol D }\end{array}$ & Li \& Kusari (2017) \\
\hline
\end{tabular}


Table 2 Continued.

\begin{tabular}{|c|c|c|c|c|}
\hline Sr. No. & Fungal Endophyte & Host Plant & Anticancer Compound & References \\
\hline 15. & Eutypella spp. & $\begin{array}{l}\text { Etlingera } \\
\text { littoralis }\end{array}$ & Eutypellin & Isaka et al. (2009) \\
\hline 16. & $\begin{array}{l}\text { Fusarium } \\
\text { nematophilum }\end{array}$ & $\begin{array}{l}\text { Camptotheca } \\
\text { acuminata }\end{array}$ & Camptothecin & Su et al. (2014) \\
\hline \multirow[t]{3}{*}{17.} & Fusarium oxysporum & $\begin{array}{l}\text { Catharanthus } \\
\text { roseus }\end{array}$ & Vincristine & Yang et al. (2004) \\
\hline & & $\begin{array}{l}\text { Ephedra } \\
\text { fasciculata }\end{array}$ & Beauvericin & Zhan et al. (2007) \\
\hline & & $\begin{array}{l}\text { Cylindropuntia } \\
\text { echinocarpus }\end{array}$ & Bikaverin & \\
\hline 18. & Fusarium solani & $\begin{array}{l}\text { Camptotheca } \\
\text { acuminata }\end{array}$ & $\begin{array}{l}\text { Camptothecin, } \\
\text { 9-Methoxycamptothecin }\end{array}$ & $\begin{array}{l}\text { Kusari et al. (2009b), } \\
\text { Ran et al. (2017) }\end{array}$ \\
\hline & & $\begin{array}{l}\text { Podophyllum } \\
\text { hexandrum }\end{array}$ & Podophyllotoxin & Nadeem et al. (2012) \\
\hline 19. & $\begin{array}{l}\text { Annulohypoxylon } \\
\text { truncatum }\end{array}$ & $\begin{array}{l}\text { Artemisia } \\
\text { апnиa }\end{array}$ & Daldinone & Gu et al. (2007) \\
\hline 20. & $\begin{array}{l}\text { Lasiodiplodia } \\
\text { theobromae }\end{array}$ & $\begin{array}{l}\text { Morinda } \\
\text { citrifolia }\end{array}$ & Taxol & Pandi et al. (2011) \\
\hline 21. & Neurospora crassa & $\begin{array}{l}\text { Camptotheca } \\
\text { acuminata }\end{array}$ & Camptothecin & Rehman et al. (2008) \\
\hline 22. & Pestalotiopsis fici & $\begin{array}{l}\text { Camellia } \\
\text { sinensis }\end{array}$ & Pestaloficiol & Ling et al. (2009) \\
\hline 23. & Penicillium dodgei & $\begin{array}{l}\text { Pinellia } \\
\text { ternata }\end{array}$ & Dehydropaxilline & Gao et al. (2017) \\
\hline \multirow[t]{3}{*}{24.} & Penicillium spp. & Aegiceras & Leptosphaerone & Lin et al. (2008) \\
\hline & & $\begin{array}{l}\text { corniculatum } \\
\text { Annona } \\
\text { squamosa }\end{array}$ & $\begin{array}{l}\text { Penicillenone } \\
\text { Meleargine, } \\
\text { Chrysogine }\end{array}$ & Yunianto et al. (2014) \\
\hline & & $\begin{array}{l}\text { Tabebuia } \\
\text { argentea }\end{array}$ & Lapachol & $\begin{array}{l}\text { Channabasava \& } \\
\text { Govindappa (2014) }\end{array}$ \\
\hline \multirow[t]{3}{*}{25.} & $\begin{array}{l}\text { Pestalotiopsis } \\
\text { microspora }\end{array}$ & $\begin{array}{l}\text { Torreya } \\
\text { taxifolia }\end{array}$ & Torreyanic acid & Lee et al. (1996) \\
\hline & & $\begin{array}{l}\text { Taxus } \\
\text { wallichiana }\end{array}$ & Paclitaxel & Stierle et al. (1993) \\
\hline & & $\begin{array}{l}\text { Artocarpus } \\
\text { heterophyllus }\end{array}$ & Hydroxypestalotin & Riga et al. (2019) \\
\hline 26. & Pestalotia photiniae & $\begin{array}{l}\text { Roystonea } \\
\text { regia }\end{array}$ & Photinides & Ding et al. (2009) \\
\hline 27. & Pestalotiopsis spp. & $\begin{array}{l}\text { Rhizophora } \\
\text { mucronata }\end{array}$ & Pestalotiopsone & Xu et al. (2009) \\
\hline 28. & $\begin{array}{l}\text { Pestalotiopsis } \\
\text { terminaliae }\end{array}$ & $\begin{array}{l}\text { Terminalia } \\
\text { arjuna }\end{array}$ & Paclitaxel & $\begin{array}{l}\text { Gangadevi \& } \\
\text { Muthumary (2008) }\end{array}$ \\
\hline 29. & $\begin{array}{l}\text { Phialocephala } \\
\text { fortinii }\end{array}$ & $\begin{array}{l}\text { Podophyllum } \\
\text { peltatum }\end{array}$ & Podophyllotoxin & Eyberger et al. (2006) \\
\hline 30. & $\begin{array}{l}\text { Phomopsis } \\
\text { longicolla }\end{array}$ & $\begin{array}{l}\text { Dicerandra } \\
\text { frutescens }\end{array}$ & Dicerandrol & $\begin{array}{l}\text { Wagenaar \& Clardy } \\
\text { (2001) }\end{array}$ \\
\hline \multirow[t]{2}{*}{31.} & Phomopsis spp. & $\begin{array}{l}\text { Musa } \\
\text { acuminata }\end{array}$ & Oblongolide & $\begin{array}{l}\text { Taridaporn et al. } \\
\text { (2010) }\end{array}$ \\
\hline & & $\begin{array}{l}\text { Tectona } \\
\text { grandis }\end{array}$ & Phomoxanthone & Isaka et al. (2001) \\
\hline 32. & $\begin{array}{l}\text { Phyllosticta } \\
\text { spinarum }\end{array}$ & $\begin{array}{l}\text { Platycladus } \\
\text { orientalis }\end{array}$ & Tauranin & $\begin{array}{l}\text { Wijeratne et al. } \\
(2008)\end{array}$ \\
\hline 33. & Rhinocladiella spp. & $\begin{array}{l}\text { Tripterygium } \\
\text { wilfordii }\end{array}$ & Cytochalasin & Lee (1995) \\
\hline
\end{tabular}


Table 2 Continued.

\begin{tabular}{|c|c|c|c|c|}
\hline Sr. No. & Fungal Endophyte & Host Plant & Anticancer Compound & References \\
\hline 34. & $\begin{array}{l}\text { Rosellinia sancta- } \\
\text { cruciana }\end{array}$ & $\begin{array}{l}\text { Albizia } \\
\text { lebbeck }\end{array}$ & Jammosporin A & Sharma et al. (2018) \\
\hline 35. & $\begin{array}{l}\text { Stemphylium } \\
\text { globuliferum }\end{array}$ & $\begin{array}{l}\text { Mentha } \\
\text { pulegium }\end{array}$ & Alterporriol & Debbab et al. (2009) \\
\hline 36. & Teratosphaeria spp. & Pinus clausa & $\begin{array}{l}\text { Teratosphaerone A, } \\
\text { Monosporascone }\end{array}$ & $\begin{array}{l}\text { Padumadasa et al. } \\
\text { (2018) }\end{array}$ \\
\hline 37. & $\begin{array}{l}\text { Canariomyces } \\
\text { subthermophilus }\end{array}$ & $\begin{array}{l}\text { Hypericum } \\
\text { perforatum }\end{array}$ & Hypericin, Emodin & Kusari et al. (2009a) \\
\hline 38. & Trametes hirsuta & $\begin{array}{l}\text { Podophyllum } \\
\text { hexandrum }\end{array}$ & Podophyllotoxin & Puri et al. (2006) \\
\hline
\end{tabular}

The extensive variety of chemical compounds have been disengaged from an assortment of endophytic fungi has a place with different hosts and synthetic groups, for example, aldehydes, alkaloid, chromones, cyclohexanones, depsidones, depsipeptides, ergochromes, esters, lactones, lignans, peptides, polyketides, quinones, diterpenes, sesquiterpenes, xanthones and so forth.

Today the greater part of the bioactive agents enrolled in Table 2 are at various dimensions of phase I, phase II clinical trials (Perfect 2017) and there are apparent expectations that the vast majority of them will be affirmed for helpful use sooner rather than later. Besides, the bioactive compounds obtained from the variety of endophytes isolated from host plants will be proven as big armor against the disease of cancer.

\section{Conclusion}

The present review demonstrates the potential of endophytic fungi as a source for anticancer drug development. It is assumed that nature continues to provide bioactive compounds as bioresources for the further development of novel and improved drugs. Plant endophytic fungi offer an exciting new resource and research continues to reveal that most of the significant drugs originally thought to be produced by plants are most likely are interaction products with endophytes residing in the tissues of the host plant. With the help of modern biotechnology, biochemical techniques, bioprocess engineering, and fermentation technology, we can better understand and explore such significant fungal bioresources and make it more beneficial for human welfare. The fungal source of a desired anticancer agent is of distinguished value; as fungal fermentation provides a virtually inexhaustible source of metabolites of interest.

\section{Acknowledgements}

This research did not receive any specific grant from funding agencies in the public, commercial, or not-for-profit sectors.

\section{References}

Ainsworth GC, Sparrow FK, Sussman AS. 1973 - The Fungi: an advanced treatise. Vol. 4 A, Academic Press, New York, USA.

Alvin A, Miller KI, Neilan BA. 2014 - Exploring the potential of endophytes from medicinal plants as sources of antimicrobial compounds. Microbiological Research 169, 483-495.

Aly AH, Debbab A, Edrada-Ebel RA, Muller WEG et al. 2010 - Protein kinase inhibitors and other cytotoxic metabolites from the fungal endophyte Stemphylium botryosum isolated from Chenopodium album. Mycosphere 1, 153-162.

Aly AH, Edrada-Ebel RA, Indriani ID, Wray V et al. 2008 - Cytotoxic metabolites from the fungal endophyte Alternaria sp. and their subsequent detection in its host plant Polygonum senegalense. Journal of Natural Products 71, 972-980. 
Arnold AE. 2007 - Understanding the diversity of foliar endophytic fungi: Progress, challenges and frontiers. Fungal Biology Reviews. 21, 51-66.

Bachmann K. 1994 - Molecular markers in plant ecology. New Phytologist 126, 403-418.

Bacon CW, White JF. 2000 - Microbial endophytes. Marcel Dekker Inc., New York.

Barnet HL, Hunter BB. 1998 - Illustrated genera of imperfect fungi. $4^{\text {th }}$ ed., APS Press, St. Paul, MN.

Bashyal BP, Wijeratne EMK, Faeth SH, Gunatilaka AAL. 2005 - Globosumones A-C, cytotoxic orsellinic acid esters from the Sonoran Desert endophytic fungus Chaetomium globosum. Journal of Natural Products 68, 724-728.

Basu S, Bose C, Ojha N, Das N et al. 2015 - Evolution of bacterial and fungal growth media. Bioinformation 11(4), 182-184.

Borges WS, Borges KB, Bonato PS, Said S, Pupo MT. 2009 - Endophytic fungi: natural products, enzymes and biotransformation reactions. Current Organic Chemistry 13, 1137-1163.

Channabasava, Govindappa M. 2014 - First report of anticancer agent lapachol producing endophyte, Aspergillus niger of Tabebuia argentea and its in vitro cytotoxicity assay. Bangladesh Journal of Pharmacology 9, 129-139.

Chareprasert S, Piapukiew J, Thienhirun S, Whalley AJS, Sihanonth P. 2006 - Endophytic fungi of teak leaves Tectona grandis L. and rain tree leaves Samanea saman Merr. World Journal of Microbiology and Biotechnology 22, 481-486.

Chelius MK, Triplett EW. 1999 - Rapid detection of arbuscular mycorrhizae in roots and soil of an intensively managed turf grass system by PCR amplification of small subunit rDNA. Mycorrhiza 9, 61-64.

Chinworrungsee M, Wiyakrutta S, Sriubolmas N, Chuailua P, Suksamrarn A. 2008 - Cytotoxic activities of trichothecenes isolated from an endophytic fungus belonging to order Hypocreales. Archives of Pharmacal Research 31, 611-616.

Clapp JP, Young JPW, Merryweather JW, Fitter AH. 1995 - Diversity of fungal symbionts arbuscular mycorrhizas from a natural community. New Phytologist 130, 259-265.

Collins MM, Nair SB, Haroutian VD, Close D et al. 2005 - Effect of using multiple culture media for the diagnosis of noninvasive fungal sinusitis. American Journal of Rhizology 19(1), 41-5.

Cragg GM, Newman DJ. 2005 - Biodiversity: A continuing source of novel drug leads. Pure and Applied Chemistry 77, 7-24.

Cremasco MA, Hrizko BJ, Linda Wang NH. 2009 - Experimental purification of paclitaxel from a complex mixture of taxanes using a simulated moving bed. Brazilian Journal of Chemical Engineering 26(1): 207-218.

Cui CM, Li XM, Li CS, Proksch P, Wang BG. 2010 - Cytoglobosins A-G, cytochalasans from a marine-derived endophytic fungus, Chaetomium globosum QEN-14. Journal of Natural Products 73, 729-33.

Daenen LG, Houthuijzen JM, Cirkel GA, Roodhart JM et al. 2014 - Treatment-induced hostmediated mechanisms reducing the efficacy of antitumor therapies. Oncogene 33, 13411347.

Dastogeer KMG, Oshita Y, Yasuda M, Kanasugi M et al. 2020 - Host specificity of endophytic fungi from stem tissue of nature farming tomato (Solanum lycopersicum Mill.) in Japan. Agronomy 10, 1007-1019.

De Bery A. 1866 - Morphologie und physiologie der pilze, flechten und myxomyceten. Handbuch der Physiologischen Botanik. W. Engelmann, Leipzig, 2.

Debbab A, Aly AH, Edrada-Ebel RA, Wray V et al. 2009 - Bioactive metabolites from endophytic fungus Stemphylium globuliferum isolated from Menthapulegium. Journal of Natural Products 72, 626-631.

Deshmukh SK, Gupta MK, Prakash V, Saxena S. 2018 - Endophytic fungi: A source of potential antifungal compounds. Journal of Fungi 4(77): 1-42.

Dias DA, Urban S, Roessner U. 2012 - A historical overview of natural products in drug discovery. Metabolites 2, 303-336. 
Ding G, Song YC, Chen JR, Xu C et al. 2006 - Chaetoglobosin U, a cytochalasan alkaloid from endophytic Chaetomium globosum IFB-E019. Journal of Natural Products 69, 302-304.

Ding G, Zheng Z, Liu S, Zhang H et al. 2009 - Photinides A-F, cytotoxic benzofuranone - derived $\gamma$ - lactones from the plant endophytic fungus Pestalotiopsis photiniae. Journal of Natural Products 72, 942-945.

El-amrani M, Debbab A, Aly AH, Wray V et al. 2012 - Farinomalein derivatives from an unidentified endophytic fungus isolated from the mangrove plant Avicennia marina. Tetrahedron Leters 53, 6721-6724.

El-hawary SS, Moawad AS, Bahr HS, Abdelmohsen UR, Mohammed R. 2020 - Natural product diversity from the endophytic fungi of the genus Aspergillus. RSC Advances 10, 2205822079.

Ellis MB. 1976 - More dematiaceous hyphomycetes. Common Wealth Mycological Institute. Kew, Surrey, England.

Eyberger AL, Dondapati R, Porter JR. 2006 - Endophyte fungal isolates from Podophyllum peltatum produce podophyllotoxin. Journal of Natural Products 69, 1121-1124.

Feng Y, Ren F, Niu S, Wang L et al. 2014 - Guanacastane diterpenoids from the plant endophytic fungus Cercospora sp. Journal of Natural Products 77(4): 873-881.

Forseth IN. 2010 - Terrestrial biomes. Nature Education Knowledge 3(10): 11.

Gangadevi V, Muthumary J. 2008 - Taxol, an anticancer drug produced by an endophytic fungus Bartalinia robillardoides Tassi, isolated from a medicinal plant, Aegle marmelos Correa ex Roxb. World Journal of Microbiology and Biotechnology 24, 717-724.

Gangadevi V, Muthumary J. 2009 - Taxol production by Pestalotiopsis terminaliae, an endophytic fungus of Terminalia arjuna (arjun tree). Biotechnology and Applied Biochemistry 52, 9-15.

Gao N, Shang ZC, Yu P, Luo J et al. 2017 - Alkaloids from endophytic fungus Penicillium brefeldianum and their cytotoxic activities. Chinese Chemical Letters 28, 1194-1199.

Ge HM, Yu ZG, Zhang J, Wu JH, Tan RXJ. 2009 - Bioactive alkaloids from endophytic Aspergillus fumigatus. Journal of Natural Products 72, 753-775.

Goutam J, Sharma G, Tiwari V, Mishra A et al. 2017 - Isolation and characterization of 'Terrein' an antimicrobial and antitumor compound from endophytic fungus Aspergillus terreus (JAS2) associated from Achyranthus aspera, Varanasi, India. Frontiers in Microbiology 8, 1334.

Gu W, Ge HM, Song YC, Ding H et al. 2007 - Cytotoxic benzo[j]fluoranthene metabolites from Hypoxylon truncatum IFB-18, an endophyte of Artemisia annua. Journal of Natural Products 70, 114-117.

Guo LD, Huang GR, Wang Y. 2008 - Seasonal and tissue age influences on endophytic fungi of Pinus tabulaeformis (Pinaceae) in Dongling Mountain, Beijing. Journal of Integrative Plant Biology 50, 997-1003.

Guo LD, Hyde KD, Liew ECY. 1998 - A method to promote sporulation in palm endophytic fungi. Fungal Diversity 1, 109-113.

Guo LD, Hyde KD, Liew ECY. 2000 - Identification of endophytic fungi from Livistona chinensis (Palmae) using morphological and molecular techniques. New Phytologist 147, 617-630.

Hertweck C. 2009 - Hidden biosynthetic treasures brought to light. Nature Chemical Biology 5, $450-452$.

Hodkinson TR, Doohan FM, Saunders MJ, Murphy BR. 2019 - (eds.) Endophytes for novel biomolecules and in vitro methods in endophytes for a growing world. Cambridge Uni. Press, Cambridge. 275-340.

Hyde KD, Xu J, Rapior S, Jeevon R, Lumyong S et al. 2019 - The amazing potential of fungi: 50 ways we can exploit fungi industrially. Fungal Diversity 97, 1-136.

Isaka M, Jaturapat A, Rukseree K, Danwisetkanjana K et al. 2001 - Phomoxanthones A and B, Novel Xanthone dimers from the endophytic fungus Phomopsis species. Journal of Natural Products 64, 1015-1018.

Isaka M, Palasarn S, Lapanun S, Chanthaket R et al. $2009-\gamma-$ lactones and ent - eudesmane sesquiterpenes from the endophytic fungus Eutypella sp. BCC 13199. Journal of Natural 
Products $72,1720-1722$.

Khawar RN, Mishra A, Gond SK, Stierle A, Stierle D. 2011 - Anti-cancer compounds derived from fungal endophytes: Their importance and future challenges. Natural Product Reports 28, $1208-1228$.

Klemke C, Kehraus S, Wright AD, Konig GM. 2004 - New secondary metabolites from the marine endophytic fungus Apiospora montagnei. Journal of Natural Products 67, 1058-1063.

Kumaradevan G, Damodaran R, Mani P, Dineshkumar G, Jayaseelam T. 2015 - Phytochemical screening and GC MS analysis of bioactive components of ethanol leaves extract of Clerodendrum phlomidis (L.). American Journal of Biological and Pharmaceutical Research 2(3): 142-148.

Kusari S, Zuhlke S, Kosuth J, Cellarova E, Spiteller M. 2009a - Light-independent metabolomics of endophytic Thielavia subthermophila provides insight into microbial hypericin biosynthesis. Journal of Natural Products 72, 1825-1835.

Kusari S, Zuhlke S, Spiteller M. 2009b - An endophytic fungus from Camptotheca acuminata that produces camptothecin and analogues. Journal of Natural Products 72(1): 2-7.

Lakshmi PJ, Selvi KV. 2013 - Anticancer potentials of secondary metabolites from endophytes of Barringtonia acutangula and its molecular characterization. International Journal of Current Microbiology and Applied Sciences 2, 44-45.

Lee JC. 1995 - Isolation and structure determination of bioactive compounds from endophytic and insect-associated fungi (Ph.D. Thesis), Cornell University, New York, 9-51.

Lee JC, Strobel GA, Lobkovsky E, Clardy J. 1996 - Torreyanic acid: a selectively cytotoxic quinone dimer from the endophytic fungus Pestalotiopsis microspore. Journal of Organic Chemistry 61, 3232-3233.

Li G, Kusari S. 2017 - Epigenetic modulation of endophytic Eupenicillium sp. LG 41 by a histone deacetylase inhibitor for production of decalin containing compounds. Journal of Natural Products 80, 983-988.

Li J, Zhao GZ, Chen HH. 2008 - Antitumor and antimicrobial activities of endophytic Streptomycetes from pharmaceutical plants in rainforest. Letters in Applied Microbiology 47(6): 574-580.

Li P, Yang G, Qiu Y, Lin L, Dong F. 2015 - Paeonol produced by Chaetomium sp., an endophytic fungus isolated from Paeonia suffruticosa. Phytochemistry Letters 13, 334-342.

Lin Z, Zhu T, Fang Y, Gu Q, Zhu W. 2008 - Polyketides from Penicillium sp. JP-1, an endophytic fungus associated with the mangrove plant Aegiceras corniculatum. Phytochemistry 69, $1273-1278$.

Ling L, Liu S, Niu S, Guo L et al. 2009 - Isoprenylated chromone derivatives from the plant endophytic fungus Pestalotiopsis fici. Journal of Natural Products 72, 1482-1486.

Margulies M, Egholm M, Altman WE, Attiya S et al. 2005 - Genome sequencing in microfabricated high-density picolitre reactors. Nature 437,376-380.

Merchant SS, Helmann JD. 2012 - Elemental economy: microbial strategies for optimizing growth in the face of nutrient limitation. Advanced Microbial Physiology 60, 91-210.

Mishra BB, Tiwari VK. 2011 - Natural products: an evolving role in future drug discovery. European Journal of Medicinal Chemistry 46, 4769-4807.

Mishra Y, Singh A, Batra A, Sharma MM. 2014 - Understanding the biodiversity and biological applications of endophytic fungi: a review. Journal of Microbial and Biochemical Technology 58(4): 1-11.

Mushtaq S, Abbasi BH, Uzair B, Abbasi R. 2018 - Natural products as reservoirs of novel therapeutic agents. EXCLI Journal 17, 420-451.

Nadeem M, Mauji R, Pravej A, Ahmad MM et al. 2012 - Fusarium solani, P1, a new endophytic podophyllotoxin producing fungus from roots of Podophyllum hexandrum. African Journal of Microbiology Research 6(10): 2493-2499.

Nazir A, Rahman HA. 2018 - Secrets of plants: endophytes. International Journal of Plant Biology 9(1): 43-46. 
Omeje EO, Ahomafor JE, Onyekaba TU, Monioro PO et al. 2017 - Endophytic fungi as alternative and reliable sources for potent anticancer agents. Natural Products and Cancer Drug Discovery. $1^{\text {st }}$ ed., Farid A. Badria, Intech Open Limited, London, UK, 141-157.

Owen NL, Hundley N. 2004 - Endophytes-The chemical synthesizers inside plants. Science Progress 87, 79-99.

Padumadasa C, Xu YM, Wijeratne EMK, Artiles PE et al. 2018 - Cytotoxic and noncytotoxic metabolites from Teratosphaeria sp. FL2137, a fungus associated with Pinus clausa. Journal of Natural Products 81(3): 616-624.

Pandi M, Kumaran RS, Choi YK, Kim HJ, Muthumary J. 2011 - Isolation and detection of taxol, an anticancer drug produced from Lesiodiplodia theobromae, an endophytic fungus of the medicinal plant Morinda citrifolia. African Journal of Biotechnology 10(8): 1428-1435.

Perfect JR. 2017 - The antifungal pipeline: a reality check. Nature Reviews Drug Discovery 16(9): 603-616.

Porras-Alfaro A, Bayman P. 2011 - Hidden fungi, emergent properties: endophytes and microbiomes. Annual Review of Phytopathology 49, 291-315.

Puri SC, Nazir A, Chawla R, Arora R et al. 2006 - The endophytic fungus Trametes hirsute as a novel alternative source of podophyllotoxin and related aryl tetralin lignans. Journal of Biotechnology 122, 494-510.

Puri SC, Verma V, Amna T, Qazi GN, Spiteller M. 2005 - An endophytic fungus from Nothapodytes foetida that produces camptothecin. Journal of Natural Products 68, 17171719.

Ran X, Zhang G, Li S, Wang J. 2017 - Characterization and antitumor activity of camptothecin from endophytic fungus Fusarium solani isolated from Camptotheca acuminate. African Health Sciences 17, 566-574.

Ratnaweera PB, Silva ED, Williams DE, Andersen RJ. 2015 - Antimicrobial activities of endophytic fungi obtained from the arid zone invasive plant Opuntia dillenii and the isolation of equisetin, from endophytic Fusarium sp. BMC Complementary and Alternative Medicine $15,1-7$.

Redecker D, Kodner R, Graham LE. 2000 - Glomalean fungi from the Ordovician. Science 289, 1920-1921.

Redell P, Gordon V. 2000 - Lessons from nature: can ecology provide new leads in the search for novel bioactive chemicals from rainforest? In: Wrigley SK, Hayes MA, Thomas R, Chrystal EJT, Nicholson N. editors. Biodiversity: New leads for pharmaceutical and agrochemical industries. Cambridge, United Kingdom: The Royal Society of Chemistry 205-212.

Rehman S, Shawl AS, Kour A, Andrabi R et al. 2008 - An endophyte Neurospora sp. from Nothapodytes foetida producing camptothecin. Applied Biochemistry and Microbiology 44, 203-209.

Rey-Ladino J, Ross AG, Cripps AW, McManus DP, Quinn R. 2011 - Natural products and the search for novel vaccine adjuvants. Vaccine 29, 6464-6471.

Riga R, Happyana N, Hakim EH. 2019 - Chemical constituents of Pestalotiopsis microspore HF 12440. Journal of Applied Pharmaceutical Science 9(1): 108-124.

Rodriguez RJ, White Jr JF, Arnold AE, Redman RS. 2009 - Fungal endophytes: diversity and functional roles. New Phytologist 182, 314-330.

Roy BG. 2017 - Potential of small molecule fungal metabolites in antiviral chemotherapy. Antiviral Chemistry and Chemotherapy 25(2): 20-52.

Saha P, Talukdar AD, Chaudhary MD, Nath D. 2019 - Bioprospecting for fungal endophyte derived natural products for drug discovery. In Singh BP (ed) Advances in endophytic fungal research. Springer International Publishing 183-209.

Saikkonen K, Helander M, Faeth SH, Schulthess F, Wilson D. 1999 - Endophyte-grass herbivore interactions: the case of Neotyphodium endophytes in Arizona fescue populations. Oecologia 121, 411-420. 
Sanders ER. 2012 - Aseptic laboratory techniques: plating methods. Journal of Visualized Experiments 63: e3064.

Schurko A, Mendoza L, de Cock AWAM, Klassen GR. 2003 - Evidence for geographic clusters: molecular genetic differences among strains of Pythium insidiosum from Asia, Australia and the Americas are explored. Mycologia 95, 200-208.

Selim KA, El-Beih AA, Abd El-Rahman TM, El-Diwany AI. 2012 - Biology of endophytic fungi. Current Research in Environmental \& Applied Mycology 2(1): 31-82.

Sharma N, Kushwaha M, Arora D, Jain S, Singamaneni V, Sharma S, Shankar R, Bhushan S, Gupta P, Jaglan S. 2018 - New cytochalasin from Rosellinia sanctae cruciana, an endophytic fungus of Albizia lebbeck. Journal of Applied Microbiology 125(1): 111-120.

Song R, Wang J, Sun L, Zhang Y et al. 2019 - The study of metabolites from fermentation culture of Alternaria oxytropis. BMC Microbiology 19,35.

Song YC, Li H, Ye YH, Shan CY et al. 2004 - Endophytic naphthopyrone metabolites are coinhibitors of xanthine oxidase, SW1116 cell and some microbial growths. FEMS Microbiology Letters 241, 67-72.

Souvik K, Christian H, Michael S. 2012 - Chemical ecology of endophytic fungi: origins of secondary metabolites. Chemistry and Biology 19, 792-798.

Staniek A, Woerdenbag HJ, Kayser O. 2008 - Endophytes: exploiting biodiversity for the improvement of natural product-based drug discovery. Journal of Plant Interactions 3, 75-93.

Stierle A, Strobel G, Stierle D. 1993 - Taxol and taxane production by Taxomyces andreanae, an endophytic fungus of paciic yew. Science 260, 214-216.

Stierle AA, Stierle DB, Bugni T. 1999 - Sequoiatones A and B: novel antitumor metabolites isolated from a redwood endophyte. Journal of Organic Chemistry 64, 5479-5484.

Stierle DB, Stierle AA, Bugni T. 2003 - Sequoiamonascins A-D: novel anticancer metabolites isolated from a redwood endophyte. Journal of Organic Chemistry 68, 4966-4969.

Strobel G. 2006 - Harnessing endophytes for industrial microbiology. Current Opinion in Microbiology 9(3): 240-244.

Strobel G, Daisy B Castillo U, Harper J. 2004 - Natural products from endophytic microorganisms. Journal of Natural Products 67(2): 257-268.

Strobel G, Daisy B. 2003 - Bioprospecting for microbial endophytes and their natural products. Microbiology and Molecular Biology Reviews 66(4): 491-502.

Strobel GA, Hess WM. 1997 - Glucosylation of the peptide leucinostatin A, produced by an endophytic fungus of European yew, may protect the host from leucinostatin toxicity. Chemistry and Biology 4(7): 529-536.

Su H, Kang J, Ca OJ, Mo L, Hyde KD. 2014 - Medicinal plant endophytes produce analogous bioactive compounds. Chiang Mai Journal of Science 14, 1-13.

Sun X, Guo LD. 2012 - Endophytic fungal diversity: review of traditional and molecular techniques. Mycology 3(1): 65-76.

Tan RX, Zou WX. 2001 - Endophytes: a rich source of functional metabolites. Natural Product Reports 18, 448-459.

Taridaporn B, Seangaroon Y, Prasert S, Kitlada S, Saisamorn L. 2010 - Oblongolides from the endophytic fungus Phomopsis sp. BCC 9789. Journal of Natural Products 73, 55-59.

Taylor JE, Hyde KD, Jones EBG. 1999 - Endophytic fungi associated with the temperate palm, Trachycarpus fortunei, within and outside its natural geographic range. New Phytologist 142, 335-346.

Tedersoo L, Jairus T, Horton BM, Abarenkov K et al. 2008 - Strong host preference of ectomycorrhizal fungi in a Tasmanian wet sclerophyll forest as revealed by DNA barcoding and taxon-specific primers. New Phytologist 180, 479-490.

Turbyville TJ, Wijeratne EMK, Liu MX, Burns AM et al. 2006 - Search for Hsp90 inhibitors with potential anticancer activity: isolation and SAR studies of radicicol and monocillin I from two plant associated fungi of the Sonoran Desert. Journal of Natural Products 69, 178-184. 
Varma VC, Lobkovsky E, Gange AC, Singh SK, Prakash S. 2011 - Piperine production by endophytic fungus Periconia sp. isolated from Piper longum L. The Journal of Antibiotics 64, 427-431.

Von Arx JA. 1978 - The genera of fungi sporulating in pure culture. A.R. Gantner Verlag K.G., Vaduz, Liechtenstein.

Wagenaar MM, Clardy J. 2001 - Dicerandrols, new antibiotic and cytotoxic dimers produced by the fungus Phomopsis longicolla isolated from an endangered mint. Journal of Natural Products 64, 1006-1009.

Wang J, Huang Y, Fang M, Zhang Y et al. 2002 - A cytotoxin produced by Paecilomyces sp. and Aspergillus clavatus isolated from Taxus mairei and Torreya grandis. FEMS Immunology and Medical Microbiology 34, 51-57.

Wang S, Li XM, Teuscher F, Li D et al. 2006 - Chaetopyranin, a benzaldehyde derivative, and other related metabolites from Chaetomium globosum, an endophytic fungus derived from the marine red alga Polysiphonia urceolata. Journal of Natural Products 69, 1622-1625.

Wang Y, Xu L, Ren W, Zhao D et al. 2012 - Bioactive metabolites from Chaetomium globosum L18, an endophytic fungus in the medicinal plant Curcuma wenyujin. Phytomedicine 19(3): 364-368.

Wattier RAM, Gathercole LL, Assinder SJ, Gliddon CJ et al. 2003 - Sequence variation of intergenic mitochondrial DNA spacers (mtDNA-IGS) of Phytophthora infestans (Oomycetes) and related species. Molecular Ecology Notes 3(1): 136-138.

Wijeratne EMK, Paranagama PA, Marron MT, Gunatilaka MK et al. 2008 - Sesquiterpene quinones and related metabolites from Phyllosticta spinarum, a fungal strain endophytic in Platycladus orientalis of the Sonoran Desert. Journal of Natural Products 71, 218-222.

$\mathrm{Xu} \mathrm{J}$, Kjer J, Sendker J, Wray V et al. 2009 - Chromones from the endophytic fungus Pestalotiopsis sp. isolated from the Chinese mangrove plant Rhizophora mucronata. Journal of Natural Products 72, 662-665.

Yan L, Zhu J, Zhao X, Shi J et al. 2019 - Beneficial effects of endophytic fungi colonization on plants. Applied Microbiology and Biotechnology 103, 3327-3340.

Yang X, Zhang L, Guo B, Guo S. 2004 - Preliminary study of a vincristine-producing endophytic fungus isolated from leaves of Catharanthus roseus. Chinese Traditional and Herbal Drugs $35,79-81$.

Yunianto P, Rusman Y, Saepudin E, Suwarso WP, Sumaryono W. 2014 - Alkaloid (Meleagrine and chrysogine) from endophytic fungi (Penicillium sp.) of Annona squamosa L. Pakistan Journal of Biological Sciences. 17, 667-674.

Zhan J, Burns AM, Liu MX, Faeth SH, Gunatilaka AAL. 2007 - Search for cell motility and angiogenesis inhibitors with potential anticancer activity: Beauvericin and other constituents of two endophytic strains of Fusarium oxysporum. Journal of Natural Products 70, 227-232. 